\title{
GAMBARAN PENGETAHUAN DAN SIKAP REMAJA DENGAN KANKER SERVIKS DI SMAN 2 MODEL WATAMPONE
}

\author{
Indryani \\ AKBID Bina Sehat Nusantara \\ Alamat korespondensi : (indryani.bidanpendidik@gmail.com/082188882011)
}

\begin{abstract}
ABSTRAK
Berdasarkan data Badan Pusat Statistik pada tahun 2015 terdapat 25.805 orang dengan hasil IVA positif, pada tahun 2016 terdapat 45.925 orang dengan hasil IVA positif. Insiden yang terjadi pada tahun 2015 relatif tinggi dari tahun 2016. Berdasarkan data yang didapatkan di RSUD Tenriawaru Kelas B Kabupaten Bone, terdapat 13 perempuan dengan kanker serviks pada tahun 2015 dan 21 perempuan yang didiagnosa kanker serviks pada tahun 2016, Tujuan Penelitian ini untuk mengetahui gambaran pengetahuan dan sikap remaja putri dengan kanker serviks Di SMAN 2 Bone jenis Penelitian ini bersifat deskriptif untuk memperoleh, mendeskripsikan gambaran pengetahuan dan sikap remaja dengan kanker serviks di SMAN 2 Bone. Kesimpulan hasil penelitian ini yaitu remaja mampu menyikapi fenomena kanker serviks dengan tepat, hal ini ditunjukkan dengan 38 responden (54\%) berusaha menjauhi penyebab kanker serviks. Dari 70 responden, pengetahuan remaja putri tentang kanker serviks sebelum pemberian materi berpengetahuan baik sebanyak 10 responden (14\%), sedangkan dari 70 responden pengetahuan tentang kanker serviks setelah pemberian materi berpengetahuan baik sebanyak 32 responden (45\%). Dari 70 responden, sikap remaja putri tentang kanker serviks sebelum pemberian materi yang bersikap setuju sebanyak 26 responden $(37 \%)$, sedangkan dari 70 responden mengenai sikap remaja tentang kanker serviks setelah pemberian materi yang menyataka setuju sebanyak 38 responden (54\%). Dari hasil penelitian menunjukkan bahwa pengetahuan dan sikap remaja tentang kanker serviks sangatlah penting bagi remaja putri.
\end{abstract}

Kata Kunci: pengetahuan, Remaja, kanker serviks.

\section{PENDAHULUAN}

Kanker merupakan masalah kesehatan utama bagi masyarakat diseluruh dunia, salah satunya adalah kanker serviks. Kanker serviks atau kanker leher rahim merupakan salah satu penyakit keganasan di bidang kebidanan dan penyakit kandungan yang disebabkan oleh Human Papiloma Virus, kanker serviks mempunyai presentase cukup tinggi sebagai penyakit yang paling banyak menyerang kaum wanita. Hal ini disebabkan karena rendahnya pengetahuan masyarakat khususnya pada remaja wanita. Sehingga mengalami perubahan pola kehidupan yang memungkinkan virus penyebab kanker serviks semakin meningkat, dan diperlukan skrining untuk mendeteksi dini adanya tanda dan gejala kanker serviks. (Hamid Bahari, 2017)

Faktor risiko terbesar terjadinya kanker serviks disebabkan oleh infeksi sehingga diperkirakan kasus kanker serviks meningkat semakin tinggi setiap tahunnya. Dimana setiap 1 menit muncul satu kasus. Kanker serviks sangat berbahaya dan sering kali ditemukan pada wanita yang berusia $19-49$ tahun.

Berdasarkan survei pada tahun 2015 yang melibatkan 5.423 perempuan di Asia yang dilakukan pada sembilan negara termasuk Indonesia, data menunjukkan sebagian besar perempuan yang kurang mengetahui tentang kanker serviks. Sedangkan pada tahun 2016 terdapat 6.500 perempuan yang tidak mengetahui penyebab kanker serviks. Dari insiden yang terjadi pada tahun 2016 relatif tinggi dari pada tahun 2015. Berdasarkan data Badan Pusat Statistik (BPS) pada tahun 2015 menunjukkan jumlah wanita Indonesia yang berusia 30-40 tahun sejumlah 359.507 orang, terdapat 25.805 orang dengan hasil IVA

Pada tahun 2016 dari 475.503 orang telah melakukan skrining inspeksi visual asam asetat (IVA), terdapat 45.925 orang dengan hasil IVA positif. (Depkes, 2014).

Berdasarkan data dari Provinsi Sulawesi Selatan melalui profil kesehatan Indonesia tahun 2016 melaporkan bahwa kanker serviks merupakan jenis kanker yang diderita oleh penduduk Indonesia yang paling tinggi dan menyebabkan kematian. Dari bulan Januari sampai bulan Juni tahun 2015 yang berasal dari 17 Rumah Sakit telah didiagnosis sebanyak 31 penderita kanker serviks. Sedangkan pada bulan Juli sampai bulan 
Desember sebanyak 47 penderita kanker serviks

Berdasarkan data yang diperoleh dari pencatatan rekam medik RSUD Tenriawaru Kabupaten Bone pada tahun 2016 didapatkan 13 kasus kanker servik dan pada tahun 2017 terdapat 21 kasus kanker serviks yang terjadi pada wanita yang berusia diatas 35 tahun. Data pada tahun 2017 mengalami peningkatan dari tahun sebelumnya. Penderita yang terdeteksi kanker serviks bisa terjadi karena kurangnnya pengetahuan dan cara wanita menyikapi penngetahuan tentang kanker servik tersebut, wanita tidak melakukan deteksi dini sehingga gejala seringkali ditemukan dalam stadium tingkat lanjut.

Berdasarkan data yang telah dipaparkan terlihat peningkatan angka kejadian kanker serviks setiap tahunnya. Oleh sebab itu peneliti tertarik untuk mengkaji tentang "Gambaran Pengetahuan dan Sikap Remaja dengan Kanker Serviks di SMA Negeri 2.

Berdasarkan latar belakang di atas, maka dapa dirumuskan masalah penelitian tentang Bagaimanakah Gambaran Pengetahuan dan Sikap Remaja dengan Kanker Serviks Tahun 2018 di SMA 2 Model

\section{BAHAN DAN METODE}

Lokasi, Populasi, Sampel

Lokasi penelitian dini dilakukan di di Sekolah SMA Negeri 2 Bone dengan populasi penelitian ini adalah semua siswi kelas XI di Sekolah SMA Negeri 2 Bone sebanyak 204 orang. Sampel adalah sebagian atau wakil dari populasi siswa kelas XI. Sampel dalam penelitian adalah sejumlah siswi SMAN 2 Bone sebanyak 70 responden dan menggunakan "purposive sampling" yaitu sampel yang dipilih sesuai dengan kriteria inklusi dan eksklusi.

1. Kriteria inklusi
a. Siswa SMAN 2 Bone
b. Bersedia menjadi responden
c. Berjenis kelamin perempuan

2. Kriteria eksklusi
a. Siswa SMAN 2 Bone yang sedang cuti
b. Tidak bersedia menjadi responden
c. Berjenis kelamin laki-laki

\section{Pengumpulan}

3. Data sekunder adalah data yang diperoleh dalam bentuk jadi dan telah diolah oleh pihak lain yang biasanya dalam bentuk publikasi.

4. Data primer adalah data yang dikumpulkan dan diolah sendiri oleh suatu organisasi atau perorangan langsung dari objeknya (Saryono 2014).
Pengolahan Data

5. Editing

Editing adalah tahapan kegiatan memeriksa validitas data yang masuk seperti memeriksa kelengkapan pengisian kuesioner, kejelasan jawaban, relevansi jawaban dan keseragaman suatu pengukuran.

6. Coding

Coding adalah tahapan kegiatan mengklasifikasi data dan jawaban menurut kategori masing-masing sehingga memudahkan dalam pengelompokan data.

7. Processing

Processing adalah tahapan kegiatan memproses data agar dapat dianalisis. Pemrosesan data dilakukan dengan cara memasukkan data hasil pengisian kuesioner ke dalam master tabel.

8. Cleaning

Cleaning yaitu tahapan kegiatan pengecekan kembali data yang sudah di masukkandan melakukan koreksi bila terdapat kesalahan. (Lapau, 2013).

\section{Analisa Data}

3. Analisis Univariat

Digunakan untuk mendeskripsikan variabel penelitian guna memperoleh gambaran atau karakteristik sebelum dilakukan analisi bivariat. Hasil dari penelitian ditampilkan dalam bentuk distribusi frekuensi.

4. Analisis Bivariat

Analisis bivariat yang dilakukan adalah tabulasi silang antara dua variabel yaitu variabel independen dan dependen. Analisis bivariat yang digunakan untuk mengetahui hubungan terhadap objek penelitian adalah menggunakan uji chi square.

\section{HASIL PENELITIAN}

Tabel 1 Distribusi Frekuensi Gambaran Pengetahuan Remaja dengan Kanker Serviks sebelum Pemberian Materi.

\begin{tabular}{|c|c|c|}
\hline Pengetahuan & $\mathrm{n}$ & $\%$ \\
\hline Baik & 10 & $14 \%$ \\
\hline Cukup & 22 & $31 \%$ \\
\hline Kurang & 38 & $55 \%$ \\
\hline Jumlah & 70 & $100 \%$ \\
\hline
\end{tabular}

Berdasarkan tabel 1 menunjukkan bahwa persentase pengetahuan remaja putri tentang kanker serviks di SMAN 2 Bone tahun 2018 dengan kategori baik sebesar 10 responden (14\%), cukup sebesar 22 responden (31\%) dan dengan kategori kurang sebesar 38 responden (55 $\%)$. 
Tabel 2 Distribusi Frekuensi Gambaran Pengetahuan Remaja dengan Kanker Serviks setelah Pemberian Materi

\begin{tabular}{|c|c|c|}
\hline Pengetahuan & $\mathrm{n}$ & $\%$ \\
\hline Baik & 32 & $45 \%$ \\
\hline Cukup & 24 & $35 \%$ \\
\hline Kurang & 14 & $20 \%$ \\
\hline Jumlah & 70 & $100 \%$ \\
\hline
\end{tabular}

Berdasarkan tabel 2 menunjukkan bahwa persentase pengetahuan remaja putri tentang kanker serviks di SMAN 2 Bone tahun 2018 dengan kategori baik sebesar 32 responden (45\%), cukup sebesar 24 responden (35\%) dan dengan kategori kurang sebesar 14 responden (20\%).

Tabel 3 Distribusi Frekuensi Gambaran Sikap Remaja dengan Kanker Serviks sebelum Pemberian Materi.

\begin{tabular}{|c|c|c|}
\hline Pengetahuan & $\mathrm{n}$ & $\%$ \\
\hline Setuju & 26 & $37 \%$ \\
\hline Tidaksetuju & 44 & $63 \%$ \\
\hline Jumlah & 70 & $100 \%$ \\
\hline
\end{tabular}

Berdasarkan tabel 3 menunjukkan bahwa persentase sikap remaja putrid dengan kanker serviks di SMAN 2 Bone tahun 2018 dengan kategori setuju sebesar 26 responden(37\%), kategori tidak setuju 44 responden $(63 \%)$.

Tabel 4 Distribusi Frekuensi Gambaran Sikap Remaja dengan Kanker Serviks Setelah Pemberian Materi.

\begin{tabular}{|c|c|c|}
\hline Pengetahuan & $\mathrm{n}$ & $\%$ \\
\hline Setuju & 26 & $37 \%$ \\
\hline Tidak setuju & 44 & $63 \%$ \\
\hline Jumlah & 70 & $100 \%$ \\
\hline
\end{tabular}

Berdasarkan tabel 4 menunjukkan bahwa persentase sikap remaja putri dengan kanker serviks di SMAN 2 Bone tahun 2018 dengan kategori setuju sebesar 38 responden $(54 \%)$, kategori tidak setuju 34 responden (46\%).

\section{PEMBAHASAN}

1. Pengetahuan

Pengetahuan merupakan hasil tahu dan ini terjadi setelah orang melakukan penginderaan terhadap suatu objek tertentu. Penginderaan terjadi melalui pancaindra manusia, yakni : indrapenglihatan, pendengaran, penciuman, rasa dan raba. Sebagian pengetahuan manusia diperoleh melalui mata dan telinga. Pengetahuan dan kognitif merupakan domain yang sangat penting untuk terbentuknya tindakan seseorang.

Berdasarkan tabel 1 menunjukkan bahwa persentase pengetahuan remaja tentang kanker serviks di SMAN 2 Bone tahun 2018 yaitu, kategori baik sebesar 10 responden (14\%). Hal ini disebabkan karena siswi tesebut mampu menanggapi kasus kanker serviks dan peduli tentang bahaya yang akan timbul bila seseorang terkena kanker serviks. Siswi rajin membaca dan memanfaatkan sosial media untuk mendapatkan informasi tentang penyebab, pencegahan dan pengobatan kanker servik sehingga ia dapat menghindari terjadinya kasus kanker serviks.

Kategori cukup sebesar 22 responden (31\%). Hal ini disebabkan karena siswi kurang memperhati komplikasi yang akan timbul jika seseorang terserang kanker serviks. Siswi tersebut banyak yang menggunakan sosial media ke hal-hal yang negatif dibandingkan ke hal-hal yang positif. Sehingga masih banyak siswi yang berpengetahuan cukup tentang kasus tersebut.

Kategori kurang sebesar 38 responden (55\%). Hal ini disebabkan karenasiswi yang tidak memanfaatkan sosial media dengan baik, merasa tidak peduli pada penyakit kanker serviks, dan tidak pernah mengikuti penyuluhan yang berhubungan dengan kesehatan reproduksi. Sehingga masih banyak siswi yang kurang mengetahui apa itu kanker serviks. Pengetahuan yang tinggi memiliki peran penting dalam mendidik seseorang untuk berfikir dan bertidak sesuai dengan apa yang pernah terjadi sebelumnya. Bilamana seseorang memiliki pengalaman yang rendah maka pengetahuan yang dimiki juga akan rendah.

2. Sikap

Sikap merupakan pernyataan sifat evaluasi terhadap objek. Sikap berarti kecenderungan seseorang yang kurang lebih bersifat permanen mengenai aspek tertentu dalam lingkungannya. Secara umum adalah suatu pikiran, kecenderungan dan perasaan seseorang untuk mengenal aspek-aspek tertentu pada lingkungan yang sering bersifat permanen karena sulit diubah. Komponen yang dimaksud adalah pengetahuan yang selama ini diperoleh semasa hidup, dimana sangat mempengaruhi perilaku saat bertindak. Setiap individu memberikan warna tersendiri untuk seseorang bertingkahlaku. Untuk membahas lebih 
dalam mengenai sikap, kali ini akan diulas terkait beberapa definisi sikap yang dikemukakan oleh para ahli.

Berdasarkan tabel 2 menunjukkan bahwa persentase sikap remaja putri dengan kanker serviks di SMAN 2 Bone tahun 2018 yaitu, kategori setuju sebesar 26 responden (37\%). Hal ini dapat dilihat dari sebagian besar siswi mampu menangapi tentang bagaimana mencegah, mengobati kanker serviks. Dan mampu mengatasi dengan cara menghindari segala sesuatu yang dapat mengakibatkan terjadinya kanker serviks. Dimana yang ditunjukkan responden yaitu dengan tidak melakukan hubungan seks pranikah tidak akan mengkonsumsi alkohol,tidak merokok, dan akan menjaga kebersihan reproduksinya.

Kategori tidak setuju 44 responden (63 \%). Hal ini dapat dilihat dari data responden, masih ada sebagian yang belum mampu menyikapi fenomena kanker serviks secara benar dan tepat. Sehingga masih ada 44 responden (63\%) yang tidak setuju mengenai kasus kanker serviks. Dari 70 responden pada siswa SMAN 2 Bone didapat 38 responden (54\%) yang bersikap setuju terhadap kanker serviks dengan cara menghindari segala sesuatu yang dapat menyebabkan kanker serviks.

Sedangkan dari 70 responden didapatkan hanya 32 responden $(46 \%)$ saja yang tidak setuju terhadap kanker serviks. Ini berarti masih ada sebagian remaja di SMAN 2 Bone yang belum mampu menyikapi fenomena kanker serviks secara benar dan tepat. Hal ini dikarenakan karena kurangnnya pengetahuan tentang penyebab, pencegahan, pemeriksaan, dan pengobatan kanker serviks secara dini serta bahaya dari kanker serviks tersebut.

\section{KESIMPULAN}

Meningkatnya pengetahuan dapat menimbulkan perubahan persepsi dan kebiasaan seseorang, pengetahuan juga membentuk kepercayaan seseorang serta sikap terhadap suatu hal. Perilaku yang didasari pengetahuan lebih langgeng dari perilaku yang tidak didasari pengetahuan. Remaja di SMAN 2 Bone kurang mengetahui tentang kanker serviks, hal ini ditunjukkan dengan 14 responden (20\%) yang tidak mengetahui penyebab, pengobatan dan pencegahan kanker serviks setelah pemberian materi. Remaja di SMAN 2 Bone mampu menyikapi fenomena kanker serviks dengan tepat, hal ini ditunjukkan dengan 38 responden $(54 \%)$ setelah pemberian materi, berusaha menjauhi penyebab kanker serviks dan siap berkonsultasi dengan dokter jika terdapat salah satu gejala dari kanker tersebut.

Sebagaimana kita ketahui bahwa pengetahuan tidak hanya dapat diperoleh melalui pendidikan formal saja, tetapi juga dapat diperoleh melalui media sosial dan pengalaman. Dimana internet merupakan salah satu media yang paling diminati oleh para remaja sekarang untuk memperoleh sebagian informasi termasuk kanker serviks.

\section{SARAN}

1. Bagi Lahan Penelitian

Hasil penelitian ini diharapkan agar dapat membantu siswi menambah wawasan mengenai kanker serviks serta cara pencegahan kamker serviks tersebut.

2. Bagi Peneliti Selanjutnya

Diharapkan bagi peneliti selanjutnya dapat meneliti lebih dalam dan lebih jauh lagi dengan menggunakan analisis yang berbeda.Dengan metode yang berbeda sehingga memperkaya analisis data penelitian.

\section{DAFTAR PUSTAKA}

Bahari, Hamid. 2012. Cara Mudah Atasi Keputihan. Jogjakarta

Depkes, RI, 2014. Kanker Leher Rahim. http://depkes.go.id(dikutip tgl 12/5/17)

Prawihardjo, Sarwono. 2014. IImu Kebidanan. Jakarta : P.T. BINA PUSTAKA SARWONO PRAWIHARDJO.

Samadi, Heru Priyanto. 2011. Yes, I Know Everything about KankerServiks!.Solo: PT Tiga Serangkai Pustaka Mandiri.

Perhimpunan Onkologi Indonesia (POI), 2010. Pedoman Terlaksana Kanker Serviks.

Mubarak, Wahit lqbal.2011.Promosi Kesehatan.Jogjakarta:Grahallmu.

Kelvin, Joanne Frankel, RN, MSN, AO CN, 2011. 100 Tanya Jawab Mengenai Gejala Kanker Dan Efek Samping Pengobatan Kanker. Jakarta: Salemba Medika. 